\title{
Modified Oligonucleotides: New Structures, New Properties, and New Spheres of Application
}

\author{
V. G. Metelev ${ }^{a}$ and T. S. Oretskaya ${ }^{a, 1}$ \\ ${ }^{a}$ Lomonosov Moscow State University, Department of Chemistry and Belozersky Institute of Physico-Chemical Biology, \\ Moscow, 119991Russia \\ Received September 28, 2020; revised October 10, 2020; accepted October 12, 2020
}

\begin{abstract}
Nucleic acids have made a long and arduous journey "from the bench to the bedside." At present, it can be assumed that drugs based on modified oligonucleotides will find a worthy application in personalized medicine of the future.
\end{abstract}

Keywords: modified nucleic acids, oligonucleotide therapeutics, antisense oligonucleotides

DOI: $10.1134 / \mathrm{S} 1068162021020175$

\section{INTRODUCTION}

Modified oligo- and polynucleotides have become important tools in molecular biology, biochemistry, medicinal chemistry, diagnostic procedures and are gaining a niche among the next generation of therapeutic agents. The emergence of a universal automated method for the synthesis of nucleic acid (NA) fragments has played a decisive role in the qualitative leap forward in the study of the properties and use of such compounds. The design, synthesis, and application of oligonucleotides as drugs would not have been possible if three legendary articles describing the structure of DNA had not appeared in Nature in April 1953. The first was by J. Watson and F. Crick [1], in which a three-dimensional model of DNA structure was presented for the first time. Two other articles were written by researchers from King's College, Cambridge. R. Franklin and R. Gosling presented the study of X-ray diffraction by DNA crystals [2] and M. Wilkins, A. Stokes, and H. Wilson [3] did calculations of the parameters of a double helix based on crystallographic data. The history of the discovery of the double helix is well described not only in Watson's famous book The Double Helix: Memories of the Discovery of the Structure of DNA [4], but also in a number of other books, for example, in Rosalind Franklin: The Dark Lady of DNA, published by B. Maddox in 2002 [5].

The publication of these books and modern reviews on the history of the development of nucleic acid chemistry and applications [6-8], as well as the desire of many scientists to present their work in this thematic issue of the journal, indicate that the signifi-

Abbreviations: siRNA, small interfering RNA; ASO, antisense oligonucleotide; NA, nucleic acid.

${ }^{1}$ Corresponding author: phone: +7 (916) 206-41-02; fax: +7 (495) 939-31-81; e-mail: oretskaya@belozersky.msu.ru. cance of this fantastic and enchanting event is still truly the greatest in the twentieth century, and its consequences never cease to attract the attention of scientists and historians of science.

The history of chemical synthesis of DNA began two years after the discovery of the structure of the double helix of DNA by Watson and Crick. The solution of the problem of rapid and efficient synthesis of NA fragments was the basis for the development of molecular biology, biotechnology, genetics, protein engineering, and decoding the human genome. The history of NA synthesis includes thousands of investigations by scientists from many countries of the world. The research of some was based on the achievements of others. It is impossible to list all those who contributed to the development of this area. In the first classical work published by A.M. Michelson and A.R. Todd, the synthesis of dinucleotides using compounds of trivalent phosphorus was described [9]. It was a master class for of convenient protection strategy and phosphitylation methods. For the first time, ionexchange paper chromatography was used to isolate the obtained dinucleoside phosphates, a progressive method for that time. Significant events in the history of oligonucleotide chemistry were the synthesis of the tRNA gene and the emergence of a universal automated method for the synthesis of oligonucleotides; therefore, while recognizing the merits of many chemists, the enormous contribution of H.G. Khorana and M.H. Caruthers should be noted above all [6-8, 1012]. In parallel with the improvement of methods for creating internucleotide bonds and introducing/removing protective groups, a boom began in the incorporation of modified units into DNA fragments, studying the effect of modifications on the chemical and physico-chemical properties of single- and dou- 
ble-stranded fragments and their widespread use in fundamental research, medical, and diagnostic practice.

Unmodified NA can act as an object and tool for research or impact on biological processes. However, the introduction of modified fragments into the oligonucleotide chain makes it possible to significantly expand the range of tasks, including significantly improving the penetration of DNA fragments through cell membranes, increasing resistance to the action of cellular nucleases, and enhancing thermodynamic stability of NA duplexes. The incorporation of chemically active groups into an oligonucleotide allows obtaining a variety of conjugates with molecules of peptides, dyes, etc. Postsynthetic introduction of random modifications or modifications at the 3'- and/or 5 '-end of oligonucleotides are possible, however, the most universal approach is targeted incorporation of a modified unit in a predetermined position of the oligomeric chain in the process of chemical synthesis. Modifications can be subdivided into terminal and intrachain. Substitution or introduction of additional groups can occur at the internucleotide phosphate group, carbohydrate moiety, or heterocyclic base.

The modification of oligonucleotides is aimed at improving the pharmacokinetic and pharmacodynamic properties. It is possible to distinguish some trends in the change of properties upon introduction of modifications, in particular, a change in the sugar phosphate backbone leads to an increase in nuclease stability and affinity for NA, while the addition of substituents at the 3 '- and 5'-ends significantly improves the efficiency of oligonucleotide delivery to organs and penetration into cells.

It is always important to remember that one of the fundamental properties of oligonucleotides is their capability of complementary interactions; therefore, when various modifications are introduced, one of the main tasks is to preserve the structures and functions necessary for interaction with complementary regions of target nucleic acids. It is no coincidence that the modification in most cases is aimed at the sugar phosphate backbone [13-18]. Important aspects are an increase in the specificity of binding of modified oligonucleotides to target nucleic acids or NA-binding proteins and an increase in the stability of these compounds with respect to hydrolysis by cellular nucleases. Nevertheless, modifications should not lead to the rise of toxic metabolites [13].

While previously everything was about a specific modification (the main milestones are considered to be those described in reviews [6-8, 13], including 2'-F (1964), PS (1966), 2'-O-methyl (1969), 2'-O-MOE (1978), PMO (1989), PNA (1991), NP (1994) LNA (1998), tc-DNA (2002)), today such a impressive library of oligonucleotide derivatives has been accumulated, one should speak about the families of modifications. This can be demonstrated using the exam- ple of 2',4'-bridged oligonucleotides reviewed by Wan et al. [13], which contains information about 30 -bridge analogs. Until now, such structural changes that lead to a decrease in the total charge of the modified oligonucleotide and an increase in its hydrophobicity remain in demand [19-23].

To date, 11 drugs [24] based on oligonucleotides have been approved for use in medical practice (Table 1).

Clinical trials of a number of other modified oligonucleotides (antisense oligonucleotides (ASO), small interfering RNAs (siRNA), decoy, aptamers) are ongoing. This indicates that the potential of ASO and other NA-based drugs is being realized quite successfully. The use of synthetic oligonucleotides for therapeutic purposes requires a new approach for their rational design and large-scale synthesis [36]. While more than 70 drug candidates have gone through different stages of clinical trials [6], trials have been discontinued for a significant number of ASOs. The list of oligonucleotides rejected for further use as biomedical drugs continues to grow. The reasons include an unconfirmed target in a gene, an incorrectly selected nucleotide sequence of ASO, a knockdown level achieved that is insufficient for therapy, an off-target ASO activity, and, most importantly, a therapeutic index that limits treatment.

Analyzing the data in Table 1, one can easily notice that, despite the huge number of proposed modifications, only a few (a very small part of the potentially possible) relatively simple ones are actually used. The rest, which have not yet found application as drugs, are widely used in scientific research or are at various phases of clinical trials [37-41].

The search for drugs based on variously modified oligonucleotides is reminiscent of Gödel's incompleteness theorem: any system of mathematical axioms, starting from a certain level of complexity, is either internally contradictory or incomplete [42]. The cell, and even more so the organism as a whole, is too complex, and the information about the functioning of the system is insufficient to design a kind of universal remedy for the treatment of even a unique (separate) disease. This fact is the reason that a wide range of DNA fragments, sometimes containing a set of different modifications, do not reach even the earliest stage of clinical trials, remaining in the chemical laboratory as new compounds, but not biomedical therapeutics.

Chemical synthesis of therapeutic oligonucleotides is nontrivial, and the combined effects of several modifications are often unpredictable. When choosing modifications and their positions in the NA-fragment, it is necessary to be guided by empirical testing.

The lack of an antiviral drug to combat SARS$\mathrm{CoV}-2$ has led to the use to use of various drugs that inhibit certain stages of viral replication [43]. It would have been surprising if there were no publications in which, while purely theoretically, the use of oligonu- 
Table 1. Oligonucleotides approved for use as drugs

\begin{tabular}{|c|c|c|c|c|c|}
\hline Drug & $\begin{array}{c}\text { Organization } \\
\text { (year approved) }\end{array}$ & $\begin{array}{c}\text { Internucleoside } \\
\text { phosphate }\end{array}$ & $\begin{array}{c}\text { Sugar } \\
\text { or morpholine moiety }\end{array}$ & Specific features & Ref. \\
\hline Fomivirsen & $\begin{array}{l}\text { FDA (1998), } \\
\text { EMA (1999) }\end{array}$ & PS, PO & 2'-Deoxyribose & SS & [25] \\
\hline Pegaptanib & FDA (2004) & $\mathrm{PO}$ & $\begin{array}{l}\text { 2'-F-2'-deoxypyrimidine } \\
\text { and 2'-O-methylpurine } \\
\text { nucleosides }\end{array}$ & $\begin{array}{l}\text { ss } \\
\text { 5'-Terminal PEG linker, 3', 3'- } \\
\text { internucleotide bond, aptamer }\end{array}$ & [26] \\
\hline Mipomersen & FDA (2013) & PS, PO & $\begin{array}{l}\text { 2'-Deoxyribose and 2'-O- } \\
\text { (2-methoxyethyl)ribose }\end{array}$ & $\begin{array}{l}\text { ss } \\
\text { Central part, deoxynucleotides; } \\
\text { rest of the sequence, ribonucleo- } \\
\text { tides (gapmer) }\end{array}$ & {$[27]$} \\
\hline Eteplirsen & FDA (2016) & $\begin{array}{l}\text { Diamidophos- } \\
\text { phate }\end{array}$ & $\mathrm{CH}_{3}$ & $\begin{array}{l}\text { ss } \\
\text { at } 5 \text { '-end }\end{array}$ & [28] \\
\hline Nusinersen & $\begin{array}{l}\text { FDA (2016) } \\
\text { EMA (2017) }\end{array}$ & PS, PO & $\begin{array}{l}2-O-(2- \\
\text { methoxyethyl)ribose }\end{array}$ & ss & [29] \\
\hline Inotersen & \begin{tabular}{|l|} 
FDA (2018) \\
EMA (2018) \\
\end{tabular} & PS, PO & $\begin{array}{l}2 '-O-(2- \\
\text { methoxyethyl)ribose } \\
\end{array}$ & \begin{tabular}{|l|} 
ss \\
Gapmer \\
\end{tabular} & {$[30]$} \\
\hline Patisiran & $\begin{array}{l}\text { FDA (2018) } \\
\text { EMA (2018) }\end{array}$ & $\mathrm{PO}$ & $\begin{array}{l}\text { 2'-O-methylribose and } \\
\text { 2'-deoxyribose }\end{array}$ & $\begin{array}{l}\text { ds siPHK } \\
\text { Mainly ribonucleotides; double } \\
\mathrm{T} \text { at the } 3 \text { '-end }\end{array}$ & [31] \\
\hline Volanesorsen & EMA (2019) & PS, PO & $\begin{array}{l}\text { 2'-deoxyribose } \\
\text { 2'- } O \text {-(2- } \\
\text { methoxyethyl)ribose } \\
\end{array}$ & $\begin{array}{l}\text { ss } \\
\text { Gapmer }\end{array}$ & [32] \\
\hline Givosiran & FDA (2019) & $\begin{array}{l}\text { PS at ends, the } \\
\text { rest are PO }\end{array}$ & $\begin{array}{l}2^{\prime}-\mathrm{F}(\mathrm{A} / \mathrm{C} / \mathrm{G}) \\
2^{\prime}-O \text {-methyl(A/C/G/U) }\end{array}$ & $\begin{array}{l}\text { ds siRNA } \\
\text { Three-antenna GalNAc ligand } \\
\text { L96 at the 3'-end }\end{array}$ & [33] \\
\hline Golodirsen & FDA (2019) & $\begin{array}{l}\text { Diamidophos- } \\
\text { phate }\end{array}$ & $\mathrm{CH}_{3}$ & at 5'-end & [34] \\
\hline Viltolarsen & MHLW (2020) & $\begin{array}{l}\text { Diamidophos- } \\
\text { phate }\end{array}$ & $\mathrm{H}_{3} \mathrm{C}-\mathrm{N}^{\prime} \mathrm{CH}_{3}$ & ss & {$[35]$} \\
\hline
\end{tabular}

FDA, U.S. Food and Drug Administration; EMA, European Medicines Agency; MHLW, Ministry of Health, Labor, ad Welfare of Japan; PS, phosphorothioate; PO, phosphate; ss or ds, single- or double-stranded. 
cleotides to affect the virus had been proposed. Rossi et al. [44] suggest that oligonucleotide-based therapeutic agents can target either the virus itself, inhibiting its transmembrane S-protein (spike protein) or acting on its replication proteins through disruption of NA-protein interactions (aptamers), or the viral genome through suppression of gene expression (gene silencing), mediated by siRNA or ASO. Gene silencing approaches can reduce the inflammatory effects in the lungs and other organs, which lead to death in severe cases of COVID-19.

At present, it can be assumed that modified oligonucleotides will find worthy use in the treatment of various diseases, including hereditary and orphan ones, as well as in diagnostics and in personalized medicine of the future.

\section{COMPLIANCE WITH ETHICAL STANDARDS}

The article contains no studies involving animals or humans as subjects of the study.

\section{Conflict of Interests}

The authors declare they have no conflicts of interests.

\section{REFERENCES}

1. Watson, J.D. and Crick, F.H., Nature, 1953, vol. 171, pp. 737-738.

https://doi.org/10.1038/171737a0

2. Franklin, R.E. and Gosling, R.G., Nature, 1953, vol. 171, pp. 740-741. https://doi.org/10.1038/171737a0

3. Wilkins, M.H., Stokes, A.R., and Wilson, H.R., Nature, 1953, vol. 171, pp. 738-740. https://doi.org/10.1038/171738a0

4. Watson, J.D., The Double Helix: a Personal Account of the Discovery of the Structure of DNA, New York: Atheneum, 1968.

5. Maddox, B., Rosalind Franklin: The Dark Lady of DNA, New York: HarperCollins, 2002.

6. Sudhir Agrawal and Gait, M.J., Advances in Nucleic Acid Therapeutics, ch. 1: History and Development of Nucleotide Analogues in Nucleic Acid Drugs, 2019, pp. 1-21. https://doi.org/10.1039/9781788015714-00001

7. Lundin, K.E., Gissberg, O., Smith, C.I.E., and Zain, R., Methods Mol. Biol., 2019, vol. 2036, pp. 3-16. https://doi.org/10.1007/978-1-4939-9670-4_1

8. Glazier, D.A., Liao, J., Roberts, B.L., Li, X., Yang, K., Stevens, C.M., and Tang, W., Bioconjugate Chem., 2020, vol. 31, pp. 1213-1233.

https://doi.org/10.1021/acs.bioconjchem.0c00060

9. Michelson, A.M. and Todd, A.R., J. Chem. Soc., 1955, pp. 2632-2638.

https://doi.org/10.1039/JR9550002632

10. Caruthers, M.H. and Khorana, H.G., J. Mol. Biol., 1972, vol. 72, pp. 407-426.

https://doi.org/10.1016/0022-2836(72)90154-4
11. Caruthers, M.H., Science, 1985, vol. 230, pp. 281-285. https://doi.org/10.1126/science.3863253

12. Lundin, K.E., Gissberg, O., and Smith, C.I.E., Hum. Gene Ther., 2015, vol. 26, pp. 475-485.

https://doi.org/10.1089/hum.2015.070

13. Wan, W.B. and Seth, P.P., J. Med. Chem., 2016, vol. 59, pp. $9645-9667$.

https://doi.org/10.1021/acs.jmedchem.6b00551

14. Prokhorova, D.V., Chelobanov, B.P., Burakova, E.A., Fokina, A.A., and Stetsenko, D.A., Russ. J. Bioorg. Chem., 2017, vol. 43, pp. 38-42.

https://doi.org/10.1134/S1068162017010071

15. Miroshnichenko, S.K., Patutina, O.A., Burakova, E.A., Chelobanov, B.P., Fokina, A.A., Vlassov, V.V., Altman, S., Zenkova, M.A., and Stetsenko, D.A., Proc. Natl. Acad. Sci. U. S. A., 2019, vol. 116, pp. 1229-1234. https://doi.org/10.1073/pnas.1813376116

16. Zatsepin, T.S., Oretskaya, T.S., Stetsenko, D.A., and Gait, M.J., Bioconjugate Chem., 2005, vol. 16, pp. 471489.

https://doi.org/10.1021/bc049712v

17. Dolinnaya, N.G., Zubin, E.M., Kubareva, E.A., Zatsepin, T.S., and Oretskaya, T.S., Curr. Org. Chem., 2009, vol. 13, pp. 1029-1049.

https://doi.org/10.2174/138527209788680745

18. Khomyakova, E.A., Kazanova, E.V., Zubin, E.M., Kubareva, E.A., Molochkov, N.V., Ryazanova, E.M., and Oretskaya, T.S., Russ. J. Bioorg. Chem., 2010, vol. 36, pp. 315-324.

https://doi.org/10.1134/S1068162010030064

19. Yanachkov, I., Zavizion, B., Metelev, V., Stevens, L.J., Tabatadze, Y., Yanachkova, M., Wright, G., Krichevsky, A.M., and Tabatadze, D.R., Org. Biomol. Chem., 2017, vol. 15, pp. 1363-1380.

https://doi.org/10.1039/c6ob02576e

20. Metelev, V.G. and Bogdanov, A.A., Jr., Theranostics, 2020, vol. 10, pp. 1391-1414.

https://doi.org/10.7150/thno.37936

21. Markov, O.V., Filatov, A.V., Kupryushkin, M.S., Chernikov, I.V., Patutina, O.F., Strunov, A.A., Chernolovskaya, E.L., Vlassov, V.V., Pyshnyi, D.V., and Zenkova, M.A., Molecules, 2020, vol. 25, p. 3663. https://doi.org/10.3390/molecules25163663

22. Chernikov, I.V., Meschaninova, M.I., and Chernolovskaya, E.L., Methods Mol. Biol., 2020, vol. 2115, pp. 57-77.

https://doi.org/10.1007/978-1-0716-0290-4_3

23. Osborn, M.F., Coles, A.H., Biscans, A., Haraszti, R.A., Roux, L., Davis, S., Ly, S., Echeverria, D., Hassler, M.R., Godinho, B.M.D.C., Nikan, M., and Khvorova, A., Nucleic Acids Res., 2019, vol. 47, pp. 1070-1081. https://doi.org/10.1093/nar/gky1232

24. Kuijper, E.C., Bergsma, A.J., Pijnappel, W.W.M.P., and Aartsma-Rus, A., J. Inherit. Metab. Dis., 2020. https://doi.org/10.1002/jimd.12251

25. Stix, G., Sci. Am., 1998, vol. 279, p. 50. https://doi.org/10.1038/scientificamerican1198-46b

26. Doggrell, S.A., Expert Opin. Pharmacother., 2005, vol. 6, pp. 1421-1423.

https://doi.org/10.1517/14656566.6.8.1421 
27. Hair, P., Cameron, F., and McKeage, K., Drugs, 2013, vol. 73, pp. 487-493.

https://doi.org/10.1007/s40265-013-0042-2

28. Aartsma-Rus, A. and Krieg, A.M., Nucleic Acid. Ther., 2017, vol. 27, pp. 1-3. https://doi.org/10.1089/nat.2016.0657

29. Aartsma-Rus, A., Nucleic Acid Ther., 2017, vol. 27, pp. 67-69. https://doi.org/10.1089/nat.2017.0665

30. Benson, M.D., Waddington-Cruz, M., Berk, J.L., Polydefkis, M., Dyck, P.J., Wang, A.K., Planté-Bordeneuve, V., Barroso, F.A., Merlini, G., Obici, L., Scheinberg, M., Brannagan, T.H., Litchy, W.J., Whelan, C., Drachman, B.M., Adams, D., Heitner, S.B., Conceição, I., Schmidt, H.H., Vita, G., Campistol., J.M., Gamez, J., Gorevic, P.D., Gane, E., Shah, A.M., Solomon, S.D., Monia, B.P., Hughes, S.G., Kwoh, T.J., McEvoy, B.W., Jung, S.W., Baker, B.F., Ackermann, E.J., Gertz, M.A., and Coelho, T., N. Engl. J. Med., 2018, vol. 379, pp. 22-31. https://doi.org/10.1056/NEJMoa1716793

31. Hoy, S.M., Drugs, 2018, vol. 78, pp. 1625-1631. https://doi.org/10.1007/s40265-018-0983-6

32. Yang, X., Lee, S.R., Choi, Y.S., Alexander, V.J., Digenio, A., Yang, Q., Miller, Y.I., Witztum, J.L., and Tsimikas, S., J. Lipid Res., 2016, vol. 57, pp. 706-713. https://doi.org/10.1194/jlr.M066399

33. Sardh, E., Harper, P., Balwani, M., Stein, P., Rees, D., Bissell, D.M., Desnick, R., Parker, C., Phillips, J., Bonkovsky, H.L., Daphne Vassiliou, D., Penz, C., Chan-Daniels, A., He, Q., Querbes, W., Fitzgerald, K., Kim, J.B., Garg, P., Akshay Vaishnaw, A., Amy, R., Simon, A.R., and Anderson, K.E., N. Engl. J. Med., 2019, vol. 380, pp. 549-558. https://doi.org/10.1056/NEJMoa1807838

34. Heo, Y.A., Drugs, 2020, vol. 80, pp. 329-333. https://doi.org/10.1007/s40265-020-01267-2
35. Roshmi, R.R. and Yokota, T., Drugs Today (Barc.), 2019, vol. 55, pp. 627-639.

https://doi.org/10.1358/dot.2019.55.10.3045038

36. Obika, S. and Sekine, M., Synthesis of Therapeutic Oligonucleotides, Singapore: Springer, 2018, vol. VIII, p. 284. https://doi.org/10.1007/978-981-13-1912-9

37. Zubin, E.M., Antsypovich, S.I., Oretskaya, T.S., Romanova, E.A., Volkov, E.M., Tashlitskii, V.N., and Shabarova, Z.A., Russ. J. Bioorg. Chem., 1997, vol. 23, pp. 730-736.

38. Naryshkin, N.A., Farrow, M.A., Ivanovskaya, M.G., Oretskaya, T.S., Shabarova, Z.A., and Gait, M.J., Biochemistry, 1997, vol. 36, pp. 3496-3505. https://doi.org/10.1021/bi962789p

39. Monakhova, M., Ryazanova, A., Hentschel, A., Viryasov, M., Oretskaya, T., Friedhoff, P., and Kubareva, E., J. Chromatogr. A, 2015, vol. 1389, pp. 19-27.

40. Rechkunova, N.I. and Lavrik, O.I., Photochem. Photobiol., 2020, vol. 96, pp. 440-449. https://doi.org/10.1111/php.13222

41. Khodyreva, S.N. and Lavrik, O.I., DNA Repair, 2020, vol. 90 , p. 102847. https://doi.org/10.1016/j.dnarep.2020.102847

42. Gödel, K., On Formally Undecidable Propositions of Principia Mathematica and Related Systems, 1992, Dover reprint of the 1962 Basic Books edition.

43. Kupferschmidt, K. and Cohen, J., Science, 2020, vol. 367, pp. 1412-1413. https://doi.org/10.1126/science.367.6485.1412

44. Rossi, J.J. and Rossi, D., Nucleic Acid Ther., 2020, vol. 30, pp. 129-132.

https://doi.org/10.1089/nat.2020.0868

Translated by N. Onishchenko 